\title{
Implementation of Law Protection of Work Safety for Workers: PTPN IX Persero
}

\author{
Galih Arif Pramana ${ }^{1}$, Sonhaji ${ }^{1}$, Nabitatus Sa'adah ${ }^{1}$ \\ \{Galihap7@gmail.com¹, sonhajimuh19@gmail.com² ${ }^{2}$ n4b1t4tuz@yahoo.com³
}

Fakultas Hukum, Universitas Diponegoro, Jl. Prof. H. Soedarto, S.H., Semarang, Indonesia $50275^{1}$

\begin{abstract}
Legal protections for labor safety have become a major topic of discussion in recent years, as the increasing population and development of employment opportunities pose various problems. The problem in this research is the implementation of legal protection for work safety based on Law Number 13 of 2003 concerning Manpower and Law Number 1 of 1970 concerning Work Safety and other related regulations. The approach of this research is qualitative empirical juridical with analytical descriptive writing style. The object of this research is PTPN IX Persero. The results of his research show that the protection of work safety law in PTPN IX Persero is a form of implementation of Good Corporate Governance which is generally implemented based on Law Number 13 of 2003 concerning Manpower, namely that employers are required to guarantee labor protection which is the basis for implementing work safety protection commitments that must be owned and fulfilled by the company.
\end{abstract}

Keywords: Legal protection, Labor, PTPN IX Persero.

\section{Introduction}

Labor is a development agent and economic actors both individually and in groups within a company. Its role is very significant in national economic activities in increasing productivity and welfare of the community. Manpower must be empowered, including female workers. The goal is that they have more values in the sense of being more capable, more skilled and quality so that they can make optimal contributions to national development to compete in the global era that engulfs the world. There is also the term labor which contains a broader understanding, including state officials, civil servants or the military, businessmen, laborers, laborers, unemployed and others. Article 1 number 2 of Law No. 13 of 2003 concerning Manpower, the term labor contains a general meaning, that is, anyone who is able to do work to produce goods and/or services to meet their own needs or for the community.[1] Law No. 13 of 2003 concerning Manpower has specifically regulated labor rights and obligations, but in its implementation in companies, there are still many obstacles and problems faced such as lack of fulfillment of rights and lack of company supervision of its workforce.[2] One of the supervision is work safety which aims to protect the rights of workers at work. Work safety is also important for employers to control their workers from hazards when at workplace. Protection of labor law aims to ensure the continuity of the employment relationship system without any pressure from other parties, and therefore every employer is required to carry out such protection in accordance with applicable laws and regulations. Law Number 1 of 1970 concerning Work Safety regulates the obligation of 
companies to provide workplaces and workers in carrying out work that is protected in their work safety.[3]

Legal protection of labor can be done by increasing recognition of human rights, physical and technical as well as social and economic protection through norms that apply in the work environment. In this regard, Iman Soepomo divides labor protection into three types, namely economic protection, social protection and technical protection.[4], [1] The advancement of the industrial sector and the occurrence of modernization in many ways increase the intensity of the operational work of the workers, machinery, tools and so on. New technical materials containing poisons, poor work methods, deficiencies work skills and training, lack of knowledge about new sources of danger, are sources of occupational hazards and illness.

Although the government has made regulations to provide protection for workers, in reality, there are still many workers who are negligent and do not pay attention to work safety regulations. If this things keep happening, the work accidents will continue to occur and the employer should be responsible for the incident in the work accident. PT. Perkebunan Nusantara IX, which currently has a working area in Central Java Province, manages the company's main commodities, namely rubber, sugar, drops, tea and coffee. There are 15 gardens, eight sugar factories, one agro tourism unit and one unit of downstream product production and marketing. In line with the changing business environment of the company, PT. Perkebunan Nusantara IX made a business transformation in the plantation and non-estate units. Business transformation in the plantation unit includes planting sugarcane itself in the right to cultivate (HGU) the result of conversion from rubber plants to meet the needs of sugarcane raw materials. Furthermore, PT. Perkebunan Nusantara IX will be developed into a plantation company with a rubber business as the backbone (an area of close to 50,000 Ha), and the Sugar business as one of the backbone of the company's revenue. The vast land will absorb a lot of labor, but in the field the supervision of the workforce is still somewhat lacking. A working group consisting of several workers to handle several hectares of land is only supervised by one foreman, which is less effective. In addition, the work carried out at PT. Perkebunan Nusantara IX has a high risk of causing work accidents such as physical damage, damage to production facilities, medical costs, compensation and production disruptions. PT. Perkebunan Nusantara IX is a company that uses high-tech machinery in its production process. This is likely to have a risk of work accidents. To prevent unwanted matters in the matter of work safety, employers must open themselves by obeying the applicable regulations because the main purpose of the regulation is to achieve awareness not just obedience.

Based on the description above, the identification and formulation of the main issues are as follows:

1. How is the implementation of legal protection for the work safety of workers at PTPN IX Persero?

2. What are the obstacles faced by the company in implementing legal protection, and how to overcome them?

\section{Methods}

The approach method used in this research is the empirical juridical because the type of study is legal research that studies law in action to evaluate the relationship between empirical and normative aspects. The use of the study is also to find a problem formulation which are 
sought through field research. The empirical juridical method is used to provide a qualitative description of the existing problem. This approach, which is carried out in terms of juridical lies in the use of principles approaches and principles in reviewing, viewing and analyzing problems. Meanwhile, this climbing method is done empirically or sociologically in practice or activities carried out directly in the community or the field regarding existing problems. This research is intended to examine, criticize and is expected to provide solutions to examine the problems and legal protection of labor in PTPN IX Persero.

\section{Results and Discussion}

\subsection{Overview of PT. Perkebunan Nusantara IX (Persero)}

\subsubsection{Company Profile}

PT. Perkebunan Nusantara IX (Persero) was established on March 11, 1996 and has two Divisions. First, the Annual Plant Division which cultivates and produces products from rubber, coffee, cocoa and tea. Second, the Seasonal Plant Division (Sugar Factory) which produces products from sugarcane. Perkebunan Nusantara IX currently has a working area in Central Java Province managing the company's main commodities namely rubber, sugar, drops, tea and coffee. It manages 15 units of plantations, eight sugar mills, one unit of agro tourism and one unit of production and marketing of downstream products. Business transformation in the plantation unit includes planting sugarcane itself on HGU land as a result of the conversion of rubber plants to meet the needs of sugar cane raw materials.

The company also monocultures timber cultivation on land that is less suitable for staple commodities and intercrops on marginal lands for land use such as on the right and left sides of roads and overly steep land. In addition, the company also manages horticultural cultivation in order to optimize land and increase company revenue with some fruits planted there such as oranges, dragon fruit, bananas, and plants for essential oils namely citronella. Business transformation is carried out in non-garden units, namely optimizing potential areas for agro tourism, resorts and cafes, as well as the production and marketing of downstream products. Currently PTPN IX has nine agro tourism areas, four resorts consisting of one Banaran Resort which is managed by a non-estate business unit, and three resorts managed by a garden and eight Cafe Banaran 9 Coffee and Tea. The company has also developed several downstream products to consume such as Kopi Luwak, Banaran Premium Coffee, Kaligua Tea, Semugih Tea, Sugar 9, and Nutmeg Syrup. In front of PT. Perkebunan Nusantara IX will be developed into a plantation company with a rubber business as the backbone (an area of close to 50,000 $\mathrm{Ha}$ ), and the Sugar business as one of the backbone of the company's revenue. So that it can become an agribusiness company that has a solid foundation, is highly competitive, grows and develops with partners in a sustainable manner.

\subsubsection{Vision and Mission of PT. Perkebunan Nusantara IX (Persero)}

a. Vision

"Becoming a highly competitive Agribusiness company and growing together with partners."

b. Mission 
1. Producing and selling rubber, tea, coffee, cocoa, sugar and drip products to domestic and international markets in a professional manner to generate profit growth

2. Using technology that produces value products (delivery value) desired by the market with an environmentally friendly production process.

3. Improving employee welfare, creating a healthy work environment and organizing training to maintain employee motivation in efforts to increase work productivity.

4. Developing downstream products, agro-tourism and other businesses to support company performance.

5. Building synergies with strategic business partners and the business community to realize shared prosperity.

6. Together with sugar cane farmers, supporting the government program to supply the national sugar needs.

7. Empowering all company resources and environmental potential to support national economic development through job creation.

8. Implementing the Community Development Partnership Program (PKBL) as a form of social responsibility and responsibility for the welfare of the community around the company location.

9. Maintaining environmental sustainability through plant maintenance and increased soil fertility.

\subsubsection{Commodities, Products and Work Areas}

PT Perkebunan Nusantara IX produces Ribbed Smoke Sheet (RSS) from rubber sheets that are dried and smoked correctly, and through visual inspection by trained personnel. Salam latex raw materials are produced from 12 gardens spread across Central Java covering \pm 21,867 ha. With production of $\pm 26,000$ tons per year. PT. Perkebunan Nusantara IX has 15 RSS Rubber Factories, one TPC Factory, and five BRCR Factories. All factories are certified with ISO9001: 2015 Quality Management System and 14001: 2015 Environmental Management System and Indonesian National Standard (SNI). PT. Perkebunan Nusantara IX has three Units to produce black orthodox tea, namely The Kaligua Factory, The Semugih Factory, The Jolotigo Factory with a total capacity of 12.1 tons/day. Annual production \pm 2,000 tons/year, total tea area $\pm 1,164.78$ ha. It has two garden areas, namely the altitude plateau 1,200 to 2,050 m above sea level (Kaligua Gardens) and the altitude plateau 600 to 1,200 $\mathrm{m}$ above sea level (Semugih and Jolotigo gardens). PTPN IX's tea factory is ISO 9001: 2015 Quality Management System certified and has received Rainforest Alliance certification as a sign that it has implemented Sustainable Agriculture Network (SAN) standard agricultural management.

The area of PT. Perkebunan Nusantara IX coffee plantations is spread over four estates in Central Java with an area of \pm 951.45 ha, with two types of cultivated coffee, Arabica and Robusta coffee. Coffee Plantation PT. Perkebunan Nusantara IX has a planting density of 1,000 trees per hectare that supports a sustainable ecosystem for coffee plants, as well as with trained personnel in cultivation culture and processing systems to be able to produce quality coffee and the best flavor. PTPN IX Coffee Factory has been certified with ISO 9001: 2015 Quality Management System and Environmental Management System 14001: 2015 and the National Standard of PT. Perkebunan Nusantara IX has two coffee factories with a total capacity of 35.60 tons/day which has been established since 1911.

Besides processing with modern processing equipment, coffee beans are still past the traditional sorting stage which is carried out by trained and experienced personnel. As for the types of coffee commodities: 
a. R/WP: Quality Wet Process Robusta is separated into grade 1, grade 4 and local with large, medium, small sizes ( $\mathrm{L}, \mathrm{M}, \mathrm{S}$ )

b. R/DP: Quality Dry Process Robusta are separated into grade 1, grade 4 and local with large, medium, small sizes (L, M, S)

c. A/WP: Quality Wet Process Arabica separated into grade 1 and local with large, medium, small sizes (L, M, S)

d. A/DP: Quality Dry Process Arabica separated into grade 1 and local with large, medium, small sizes (L, M, S)

There are also side commodities, namely since 2009 PT. Perkebunan Nusantara IX began to plant wood as a main commodity support. Timber is planted in monoculture and intercrop areas with varying area of 4,300 ha (monoculture) and 1,583 ha (intercrop). Various varieties planted include Sengon, Jabon, Mahogany, Teak, Myopsis, Suren and Acacia. In addition to timber, PT. Perkebunan Nusantara IX also developed essential oils from Nutmeg and Lemongrass, which were developed from its own area of 202 ha (Nutmeg) and 96.32ha (Seraiwangi) and will be developed into an area of 580.5 hectares in 2019. The main commodity, PTPN IX (Persero) also produces downstream products in the form of: Banaran Coffee, The Kaligua Powder, The Kaligua Celup, The Semugih Powder, Sugar 9 and Nutmeg 9. 9. As a means of sales, promotion and distribution, outlets have been built in the form of cafes namely Kampoeng Banaran Bawen Salatiga Coffee, Banaran 9 Coffee and Tea Guava Regency. Semarang, Banaran 9 Coffee and Tea Majenang Cilacap, Banaran 9 Coffee and Tea Setiabudi Semarang.

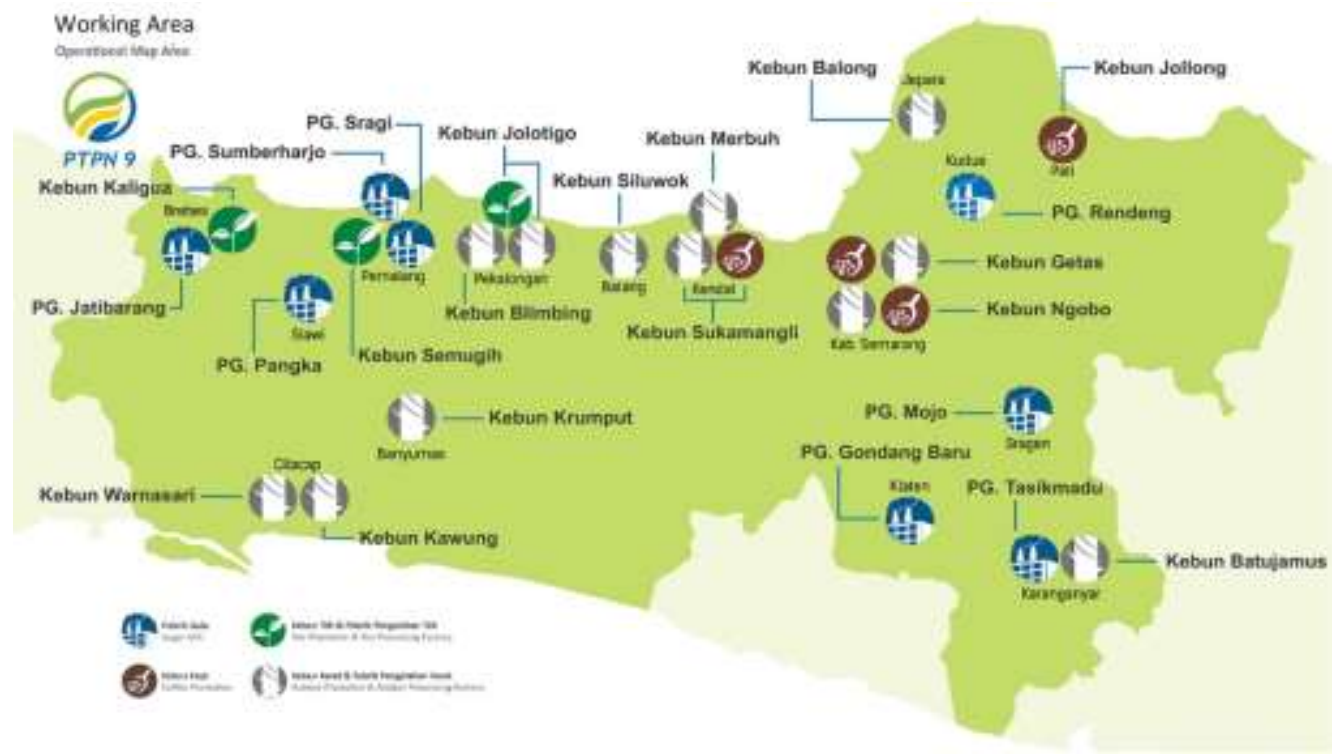

Figure 1. Working Area

\subsection{Implementation of Legal Protection for Work Safety of PT. Perkebunan Nusantara IX (Persero)}




\subsubsection{Legal Basis for Implementing Legal Protection for Work Safety of PT. Perkebunan Nusantara IX (Persero)}

PT. Perkebunan Nusantara IX (Persero) provides work safety protection for its workers which is expected to reduce the risk of accidents. PT. Perkebunan Nusantara IX (Persero) provides protection based on the Occupational Health and Safety Management System (SMK3) which prioritizes worker safety and health, cares for the environment, and cleanliness and security in the work environment. Safety at PT. Perkebunan Nusantara IX (Persero) is the company's obligation to carry out work safety protection for its workers. Safety at PT. Perkebunan Nusantara IX (Persero) is based on Law Number 13 of 2003 concerning Employment. According to the legislation, every employer is obliged to guarantee workers' protection which is the basis of the implementation of work safety protection, and it is a commitment that must be fulfilled by the company. They are all done to increase productivity and harmonious, dynamic and fair relations between employers and employees, in accordance With the applicable laws and regulations and the meaning of Industrial Relations, in PT. Perkebunan Nusantara IX (Persero), Subsidiaries and Associations/Institutions within the scope of Plantation BUMN consider it necessary to prepare a Collective Labor Agreement (PKB) whose formulation includes terms of work, rights and obligations between Employers and Employees.

Safety protection at PT. Perkebunan Nusantara IX (Persero) also refers to "BUSINESS ETHICS GUIDELINES \& Code of Conduct" PT. Perkebunan Nusantara IX (Persero). Those ethics stress the importance of implementing Good Corporate Governance as a tool to increase the value and competitiveness of the Company in facing the era of market economy and free trade. One manifestation of this commitment is the preparation and application of the Code of Conduct, a written documentation of the system of values and elaboration into expected attitudes and behavior standards. The PTPN IX (Persero) Business Ethics and Code of Conduct guidelines are guidelines for the Board of Commissioners, Directors and Employees to behave in carrying out daily tasks, interacting with business partners, business partners and other parties so that they are able to maintain and maintain the trust of the Company's Stakeholders.

Safety protection at PT. Perkebunan Nusantara IX (Persero) is also based on Law No. 1 of 1970 concerning Occupational Safety Work safety is essentially a protection for workers where they get protection for their safety rights in doing their works. The goal is to increase production and productivity by guaranteeing the safety of every worker to work safely and efficiently. Therefore, work safety protection carried out and sought by each party, both employers and workers are expected to prevent or at least reduce the danger of accidents work.

\subsubsection{The purpose of implementing Legal Protection for Work Safety of PT. Perkebunan Nusantara IX (Persero)}

PT. Perkebunan Nusantara IX (Persero) provides work safety protection for its workers with the aim to:[5]

1. Provide work equipment in accordance with $\mathrm{K} 3$ requirements so that their safety is guaranteed and their productivity is well maintained.

2. Protect production equipment and materials so that they can be used safely and efficiently.

3. Prevent and reduce work accidents and fires.

4. Create a safe and comfortable work environment. 


\subsubsection{Form of Implementation of Legal Protection for Work Safety of PT. Perkebunan Nusantara IX (Persero)}

\section{Medical examination}

PT. Perkebunan Nusantara IX (Persero) is carried out to fulfill two needs to diagnose and provide therapy for workers who suffer from common ailments. To conduct prevention and diagnose occupational diseases and determine the degree of disability. This is done by medical examiners either form professional medical workers or doctors.

Workers health checks (initial, periodic, special,) are performed by medical examiners of labor who have been authorized by the government (depnaker) to carry out medical examinations of workers. The doctors must make a report on their inspection activities during a year to the local Labor Department office once a year.

Worker health inspection (before work) according to Minister of Manpower and Transmigration Regulation No. Per.02/MEN/1980 Concerning Workers' Health Examinations in the Implementation of Occupational Safety Article 2 paragraph (2), the results of the initial examination can be used as a comparison to the data on the results of periodic health examinations to determine the existence of occupational diseases.[6] This examination includes:

\section{Anamnesa (interview)}

In this case, the employee is asked about the history of the disease, all the illnesses suffered, the perceived health condition, the history of hospital care, the history of surgery, and habits such as smoking, drinking and so on. the employee is also asked about all the work that has been done in any section, how long have their been working, and whether or not they are examined beforehand.

1. Accidents that have suffered

2. Age

3. Education

4. Family circumstances

5. And others

Anamnesa (interview) specifically for diseases:

1. Allergy

2. Epilepsy

3. Heart abnormalities

4. Blood pressure

5. Tuberculosis (TB)

6. Diabetes

7. Asthma, bronchitis, pneumonia

8. Mental disorders

9. Skin disease

10. Hearing disease

11. Lumbago

12. Disorders of the foot

13. And others 


\title{
Clinical examination
}

Like clinical examinations for common ailments, pay more attention to the possible influence of factors in the work environment.

\section{Mental examination}

The state of awareness, attitudes and behavior, mental contact, attention, initiative, intelligence, and thought process.

\section{Physical examination}

Physical diagnostics from all parts of the body by inspection, palpation, percussion and auscultation, measurement of blood pressure, pulse, breathing, height, weight, examination of visual acuity, hearing, touch, touch, reflexes, physical fitness.

\section{Laboratory examination}

To help make the diagnosis (blood, urine)

\section{Special inspection}

Special checks are carried out to see and assess the health conditions of the workforce associated with the type of work to be done, for example: Rongent chest, Alergites, spirometry, color blind and others.

\section{Preliminary workforce health examination results}

1. Healthy, and (no abnormalities) allowed to work without conditions

2. Allowed to work hard

3. Allowed to work lightly

4. Allowed to work in various parts

\section{Suffering from illness/abnormalities:}

Employee allowed to work in certain work conditions, such as network work, work in dusty areas, no contact with chemicals, and others. Refused to work rejected permanently (fixed) or rejected while waiting for the treatment process.

Periodic health checks and periodic examinations according to Minister of Manpower and Transmigration Regulation No. Per.02/MEN/1980 Concerning Workers' Health Examinations In the Implementation of Occupational Safety Article 3 paragraph (1), the provisions in the legislation must be carried out at least once a year, in accordance with the factor of the level of danger that threatens the health of the workforce, company doctors/doctor examinations can determine the duration of periodic medical examinations (more than once a year). Data from the results of periodic and special health checks can be used to find or determine the presence of occupational diseases. This examination includes:

\author{
Anamnesa (interview) \\ 1. Name \\ 2. Age \\ 3. Gender \\ 4. Work Unit \\ 5. Long time of work
}


6. Overview of what was done, the hazard factors in the work environment, complaints suffered, perceived health conditions.

\section{Clinical examination:}

1. Mental examination (mental disorders and mental illness)

2. Physical examination of all parts of the body, especially parts of the body that have abnormalities/complaints by inspection, palpation, percussion and auscultation methods, measurement of blood pressure, pulse, respiration, height, weight, examination of visual and hearing acuity, blood laboratory examination and urine and special tests related to complaints/perceived health problems and the possibility of exposure to hazardous substances in the work environment (biological monitoring) such as: roentgen chest, spirometry test, examination of special organ functions.

Results of periodic/periodic workforce health checks and special examinations:

1. Healthy

2. Pain

3. Common illness

4. Occupational diseases

5. Suspected of occupational diseases, which require further special examination in the form of work environment, special laboratory.

If it is found an employee suffers from illness, special diseases caused by work need to be given advice - control. Conduct periodic health checks, this is done with the aim to prevent and improve health as an effort to protect work safety. In addition, as an effort to improve work safety.

\section{Worker Safety Training}

Work safety activities include work safety training or training. All workers must participate actively in this activity. This activity is intended to provide an explanation of the importance of using work safety tools when doing work to reduce the number of work accidents and to anticipate emergencies that occur in the work environment.

The other purpose of holding this training is to give and improve understanding to participants regarding experience, knowledge, physical and non-physical skills of occupational safety and health. The specific goal is to make everyone aware of the potential dangers that could be encountered in the workplace or the possibility of illness caused by work accidents. Then the person who remains and is always alert to the dangers that occur at work will be formed. Not only that, participants will also better understand how prevention should be done at the workplace.

This is in accordance with Article 9 of Law Number 1 of 1970 concerning Work Safety which states that the management is required to show and explain to each new employee:

1. Conditions and hazards and which may arise in the workplace.

2. All safeguards and protective devices that are required in the workplace.

3. Personal protective equipment for the workforce concerned;

4. Safe ways and attitudes in carrying out their work.

Management is also required to provide guidance for all workers under its leadership such as preventing accidents and combating fires and improving occupational safety and health, as well as in providing first aid in accidents. Implementation of the Occupational Safety and 
Health (K3) system at PT. Perkebunan Nusantara IX (Persero) based on observations made are as follows:

\section{Personal Protective Equipment (PPE)}

According to the Minister of Manpower and Transmigration Regulation No. Per.08/MEN/2010 Concerning Personal Protection Equipment Article 1 paragraph (1), personal protective equipment (PPE) is a tool that must be used when working in accordance with work hazards and risks to maintain the safety of the worker himself and those around him.[7]

The types of PPE used vary according to the type of work and place of work in the company. Based on the Minister of Manpower and Transmigration Regulation No. Per.08/MEN/2010 Concerning Personal Protection Equipment Article 2 paragraph (1), generally PPE consists of:

a. head protector;

b. eye and face protection;

c. ear protector;

d. respiratory protection and equipment;

e. hand protection; and/or

f. foot protector

In plantation work areas, workers in the tapping process must use PPE boots to protect workers' feet, hats and cloth gloves. Personal protective equipment that must be used by latex processing workers are masks, aprons, goggles and boots. Personal protective equipment that must be used by grinding workers is boots, aprons, and gloves to protect the hands when grinding rubber with a grinding machine. Workers in smoke houses are required to wear masks, goggles, and boots so that smoke and dust do not interfere with breathing workers and workers in the sorting line are required to use PPE gloves and masks.

2. Fire Danger Protection and Prevention

In an effort to prevent fire and protect fire hazards, PT. Perkebunan Nusantara IX include:

a. Make an effort to form a fire brigade team. Fire team members are divided into two divisions. The first division is the electrical and engine installation security division whose duty is to cut off the flow of electricity on the equipment that is burning and isolate or block the flow of electricity that is associated with fires to prevent the spread of fires on other equipment. Meanwhile, the second division, namely the APAR division, is tasked with carrying out initial phase outages for the minor fire class, suppressing special equipment and electricity or electronics and assisting in the ongoing advanced phases.

b. Hold fire training. This training aims to enable employees to respond to emergencies in the event of a fire, and that the fire department can carry out its duties. Fire training is conducted in the form of fire simulation. This simulation is in the form of an emergency scenario designed to illustrate the readiness of PT. Perkebunan Nusantara IX in an emergency (fire) by involving all employees in the factory environment.

c. Evacuation route. The path is green and the writing is white, which is posted on the wall with a view of view in general visible to everyone. This path leads to the evacuation gathering area or out of the room. There are three stages of fire fighting associated with the stages of a fire, these stages include:[8]

1. Extinguish the fire at an early stage, 
2. Prevents fire from growing, and

3. Control smoke.

\section{Extinguish Early Stage Fire}

Almost every fire starts from a small fire, however, when it is not immediately responded to, the fire will be enlarged or even spread in an area. Based on this, to detect early the presence of fire needed a detector for the occurrence of fires even needed an alarm if there is a flammable gas leak.

Early fire fighting is a very important step in preventing the occurrence of larger fires. Fire fighting that is still small requires the right tools and quick action. Tools needed at this stage are Light Fire Extinguisher (APAR), Hydrant which provides high-pressure water, fixed systems that are usually installed in buildings, and other equipment around that can be used for the process of extinguishing fires such as gunny sack, blankets, and similar items that can absorb water and close the fire to separate it from the air.

APAR is a fire extinguisher which is very popular among the people, however most of them do not know the type and how to use it. APAR has many types, depending on the ability to extinguish fires on certain types of fuel. Most people do not know how to use APAR, to find out it requires knowledge of the parts/components of APAR tubes and the steps for their use.

APAR placement must meet the requirements so that when a letter fire occurs, it can be reached quickly. These conditions include:

1. Easily visible,

2. Easy to Afford,

3. scattered/not concentrated in one location,

4. unlocked, and according to the situation and conditions.

How to use APAR is actually very easy, the steps include:

1. open the safety lock,

2. hold the APAR tube in an upright position,

3. press the opening handle of the extinguishing material,

4. direct the spray of fire that is burning/not directed at the fire,

5. spray APAR, periodically (every 3 seconds period) if it is operated continuously APAR can only be operated for 8 seconds

\section{Prevents Fire from Growing}

If the fire is not quickly controlled and is getting bigger, further steps are needed that aim to localize the fire, cool it down, and decompose the burning material. Fire prevention is done by separating the three elements of fire. In three different ways, namely: isolation, cooling, and decomposition. The implementation of these three types of application depends on the situation and condition when a fire occurs, therefore, in the event of a fire we must be biased in making decisions as to which methods can be applied.

\section{Control Smoke}

Most of the burning material produces smoke. Smoke in the form of gas containing various elements which is very dangerous to health. Even many fatalities in the event of fire caused by excessive inhalation of smoke. Therefore the emergence of smoke must be handled properly. Smoke handling can be done in several ways, including:

1. the application of the air system according to standards in a building, 
2. installation of smoke detection devices, and

3. installation of smoke vent installation.

\section{APAR (Light Fire Extinguisher)}

PT. Perkebunan Nusantara IX (Persero) has APAR installed with a radius of 20-25 meters. PT. Perkebunan Nusantara IX (Persero) has not been able to install APAR with a distance of 15 meters every 1 APAR in accordance with the provisions of APAR installation. This fire extinguisher is placed in an easily accessible place with a height of $120 \mathrm{~cm}$.

\subsection{Obstacles and Efforts Made in the Implementation of Legal Protection for Work Safety at PT. Perkebunan Nusantara IX (Persero)}

\subsubsection{Barriers to the Implementation of Legal Protection for Work Safety at PT. Perkebunan Nusantara IX (Persero)}

In the implementation of Legal Protection for Work Safety in PT. Perkebunan Nusantara IX (Persero) there are several obstacles. The obstacles are as follows:

a. Lack of awareness about the importance of occupational health and safety.

According to Law No. 1 of 1970 concerning Safety of Work, the government requires all business sectors to implement Occupational Safety and Health (K3) in the workplace as a form of professionalism. The law explains the importance of fulfilling work safety requirements to prevent, reduce and control accidents, detonation hazards, temperature, humidity, radiation, sound, vibration, electrical hazards, extinguishing fires, rescue assistance and personal protective equipment (PPE) ) to workers. Thus, companies engaged in any line of business are required to apply $\mathrm{K} 3$ in the workplace. In the implementation the level of awareness of using personal protective equipment is still lacking. When working, many workers ignored the use of personal protective equipment and only wore ordinary everyday clothing in carrying out the work both in the stages before production and after the production phase takes place.[9] In addition, there were also some PPE that were lost or were not suitable to wear.

This is a common problem, namely the lack of awareness about the importance of health and safety at work. Many workers at PT. Perkebunan Nusantara IX (Persero) is still indifferent or not so concerned with work safety. Workers are not all aware of the dangers of accidents on the ground, so the culture and behavior of using PPE is still often ignored. This lack of safety culture is characterized by socio-cultural gaps in the form of low discipline and employee awareness of work safety issues. The behavior of workers who do not fully understand the dangers inherent in industries with advanced technology and the existence of a relaxed and indifferent culture of workers in prioritizing safety in the work he does.

\section{b. $\quad$ Wide working area and difficult terrain}

PT. Perkebunan Nusantara IX (Persero) is a company engaged in the field of production, so it requires workers who are ready to use to carry out their tasks every day. The working area in the form of large plantations which are sometimes located on hills such as being surrounded by steep slopes and near large rivers. During the rainy season, it will be more dangerous. The place has a risk of increasing the number of accidents experienced by workers at PT. Perkebunan Nusantara IX (Persero). Difficult land will also result in the evacuation process proceeding rather slowly in the event of a work accident that befalls one of its workers. The most common causes of work accidents are unsafe environmental conditions and unsafe behavior. The causes of accidents so far are caused by unsafe behavior such as being 
careless and careless, not complying with regulations, not following standard procedures work, not wearing personal protective equipment, as well as a weak body condition.

\subsubsection{Efforts in Overcoming Barriers to the Implementation of Legal Protection for Work Safety at PT. Perkebunan Nusantara IX (Persero)}

The efforts made by PT. Perkebunan Nusantara IX (Persero) in overcoming obstacles to implementing legal protection for work safety are as follows:

a. $\quad$ Efforts to increase worker awareness

Overcoming these obstacles certainly cannot be overcome once in a while, therefore

the company has efforts in overcoming these obstacles, namely:

1. Safety Induction, it is a fundamental program in disciplining its employees by providing induction and orientation about work and aspects of work safety. Induction is carried out mainly for new or newly transferred employees. Induction is also applied to guests or contractors who will enter the company area.

2. Training and Coaching. Training has the aim to provide knowledge and expertise that supports work functions. Whereas coaching is a direct communication medium between superiors and subordinates to encourage individual development.

3. Re-Training, namely by refreshing one's knowledge and expertise to maintain ability.

4. Counseling. It is a forum to explore problems or problems that cause a decrease in a person's performance and encourage that person to improve his performance again.

5. Verbal warning it is a direct warning against violators, every employee has the right to reprimand and remind other employees who commit violations.

PT. Perkebunan Nusantara IX (Persero) strives to review or make company regulations in which there are arrangements regarding better work safety procedures that should be obtained by workers. This is a very important thing to be implemented because it is related to the Occupational Health and Safety of the workers themselves and has also been regulated in Law No. 13 of 2003 concerning Employment. Safety is the main work safety standard to prevent work accidents. This became the basis by PT. Perkebunan Nusantara IX (Persero) to always improve safety standards for its workers to avoid the risk of work accidents that can occur at any time. Work safety measures can include the following:

1. Body protection, including protection of eyes, hands, nose, feet, head and ears.

2. Machine protection, as a protective measure against machines that may arise from outside or from within or from the workers themselves

3. Electric safety devices, which can be dangerous at any time.

4. Space safety, including alarm systems, fire extinguishers, adequate lighting, hydrant water, good air ventilation.

b. $\quad$ Efforts to overcome broad work areas and difficult terrain

Supervise to support the implementation of the program K3 well, by:

1. Work safety supervision.

2. Occupational health surveillance.

3. Supervision of the work environment.

Activities in work safety supervision are supervision of work machinery and equipment, work procedures, work attitudes, personal protective equipment, and 
investigation of accidents that have occurred, while supervision of occupational health includes:

1. Employee health check, both old employees and new employees.

2. Supervision of the quality of drinking water in the company.

3. Supervision of occupational diseases.

4. Supervision of workplace cleanliness.

Supervision of the work environment, the activities carried out include supervision of physical disturbances, namely noise, workplace temperature, lighting and vibration. In addition, supervision is also carried out on disturbances caused by chemicals such as dust, gas, or chemical liquids. Based on interviews, it is known that the company provides various $\mathrm{K} 3$ facilities and advice, namely:

1. Personal Protective Equipment (PPE)

2. K3 facilities and facilities: provision of first aid kits in each section, provision of clean water and toilets, drinking water supply, supplementary food in the form of bread and milk for employees who work night shifts, canteens, cooperatives, rest areas, and polyclinics with medical staff who are always ready standby

3. Insurance, including accident insurance and health insurance in collaboration with Jamsostek.

Efforts made by the company in overcoming these obstacles are by giving the right to anyone who sees a friend or fellow employee to reprimand and warn about the danger being violated, and for every employee who sees a violation/condition that allows an accident to arise then for report it to the party appointed by the company. In addition, the company implements programs such as safety induction, training and coaching, retraining, counseling, verbal warning/reprimand, and supervision.

\section{Conclusion}

The implementation of legal protection for work safety at PTPN IX Persero is a form of implementing Good Corporate Governance as a tool to increase the value and competitiveness of companies in facing the era of market economy and free trade. Legal protection for work safety in PTPN IX Persero is generally implemented based on Law No. 13 of 2003 concerning Manpower, which states that employers are required to guarantee workers protection, which is the basis of implementing work safety protection and commitment that must be fulfilled by the company. Legal protection for work safety at PTPN IX Persero is further regulated in Act Number 1 of 1970 concerning Work Safety and several ministerial regulations that specifically regulate matters relating to labor safety.

The obstacle that often occurs is that there is often a lack of awareness about using personal protective equipment. When working, many workers neglected the use the personal protective equipment and only wore an ordinary everyday clothing in carrying out the work both in the before-production and after-production stage. Other problems include vast area and several fields that are not managed. To overcome this, more incentive monitoring efforts are carried out.

The suggestions for development are about the legal protection for work safety at PTPN IX Persero. The company should update the way or technical implementation of work safety 
protection to adjust to the changing times, and new sophisticated machines. It is hoped that labor safety standards become higher. The role of the government in protecting the rights of labor as a weak party is obviously needed by guaranteeing employee to get insurance since their work is mostly outside the room. 


\section{References}

[1] A. Khakim, Hukum Ketenagakerjaan Indonesia. Bandung: PT. Citra Aditya Bakti.

[2] Law Number 13 of 2003 concerning Manpower. .

[3] "Law Number 1 of 1970 concerning Work Safety."

[4] I. Soepomo, Pengantar Hukum Perburuhan. Jakarta: Penerbit Djambatan, 1987.

[5] Article 48-49 Collective Labor Agreement of PT. Perkebunan Nusantara 2018. .

[6] Minister of Manpower and Transmigration Regulation No. Per.02/MEN/1980 Concerning Workers' Health Examinations in Implementing Occupational Safety. .

[7] "Minister of Manpower and Transmigration Regulation No. Per.08/MEN/2010 Concerning Personal Protection Equipment."

[8] K. I. et al. Ismara, Keselamatan dan Kesehatan Kerja (K3). Yogyakarta: FT UNY, 2014.

[9] Interview with Giyarto, the field supervisor of PT. Perkebunan Nusantara IX Persero, Bringin, January 23, 2019. . 